\section{JURNAL ABDIMAS

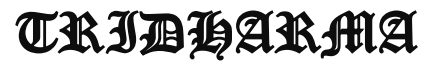 \\ AtA}

P-ISSN 2615-6849, E-ISSN 2716-070X

Jurnal ABDIMAS Vol. 2,No.3, Agustus 2021,Hal(33-39)

@ Prodi Manajemen Fakultas Ekonomi Universitas Pamulang

Email: abdimasjurnal.unpam@gmail.com Telp: (021) 741-2566

\title{
PENYULUHAN DAN PEMBERIAN MATERI DAN DEMO/PRAKTEK PELATIHAN SALON KECANTIKAN KHUSUS PEMASANGAN BULU MATA DENGAN KONSENTRASI PADA PENGELOLAAN KEUANGAN
}

\author{
Akhmad Akbar, Supatmin, Hengki Hermawan, Sutiman, Nurwita \\ Dosen Fakultas Ekonomi Bisnis \\ Universitas Pamulang \\ $\frac{\text { dosen01973@unpam.ac.id, dosen01767@unpam.ac.id, dosen01781@unpam.ac.id, }}{\text { dosen01673@unpam.ac.id, nurwita01917@unpam.ac.id }}$
}

\begin{abstract}
ABSTRAK
Undang-undang No. 20 tahun 2003 pasal 20 serta pasal 24 mengatur perihal dasar hukum pelaksanaan dari salah satu tujuan Tridarma Perguruan Tinggi yaitu perihal Penelitian dan Pengabdian kepada masyaraat atau PKM. Adapun isi dari pasal tersebut perihal Sistem Pendidikan Nasional yang menyatakan bahwa adanya otonomi oleh Perguruan Tinggi, Penelitian Ilmiah dan Pengabdian Kepada Masyarakat atau PKM. Sebagai pertanggungjawaban Dosen sebagai Beban kerjanya selain mengajar, maka dalam melaksanakan tugas tersebut telah kami susun laporan kegiatan pengabdian kepada masyarakat/PKM.

Sealanjutnya pelaksanaan Pengabdian Kepada Masyarakat ini, dilakukan Pengabdian Kepada Masyarakan dengan mengangkat judul "Penyuluhan dan pemberian materi dan demo praktek salon kecantikan khusus Pemasangan Bulu Mata dengan konsentrasi pada pengelolaan Keuangan pada rumah yatim piatu". Pelatihan ini ditujukan agar warga panti asuhan dan seluruh pengelola dapat memiliki kemampuan manajemen keuangan yang baik dan kemandirian dalam berwirausaha. Hal tersebut disiapkan sejak dini dari awal dimulainya kegiatan wirausaha agar kedepannya kemampuan ini dapat mendukung proses berwirausaha dengan sangat maksimal dan tepat perhitungan sehingga usaha yang ditekuni dapat berkembang terus menerus dari waktu ke waktu serta dapat membentuk kemandirian dalam berwirausaha.

Sesuai dengan perihal tersebut diatas maka akan dilaksanakan Pengabdian Kepada Masyarakat (PKM) di Rumah yatim piatu Al-Amien, Ciater Kota Tangerang Selatan. Dimana saat ini anak - anak panti asuhan Al - Amien sudah memulai merintis usaha secara bersama - sama guna mengajarkan dan mendidik kemandirian. Rintisan usaha tersebut masih dikelola secara sederhana oleh anak - anak panti asuhan dengan manjemen pengelolaan yang belum baik dan masih bersifat rutinitas, terutama mengenai pentingnya pengelolaan manajemen keuangannya.
\end{abstract}

Kata Kunci : Kewirausahaan, Manajemen Keuangan

ABSTRACT 
The Law no. 120 of 2003 articles 20 and of articles 24 of the set regarding the legal basis of one of the objectives of Tridarma of Higher namely regarding research and Community Service (PKM. As for the contents of the articles regarding national educational system shows that the existence of autonomy by a college, scientific research and Community Service orPKM. As he got from his lecturers accountability as their workload in addition to teaching, so in carrying out tasks has been we aligned the reports on the Community Service orPKM.

The devotion to the implementation of this community service, done devotion to communities by lifting the title counseling and the provision of material and implementation special "beauty Salon" practice the eyelash with concentrate on financial management in the orpha. This training is that residents foster homes and all managers can have good financial management capability and independence in intrepreneurial. It is prepared from the beginning as early as the beginning of entrepreneurial activity that in future this capability can support the process very well and right interpreneur calculations so that businesses can develop ditekuni continuous from time to time and can form interpreneur developing kind of confidence in .

According to regarding mentioned above and will be implemented devotion to the ( PKM ) will be carried out at the Al-Amien orphanage, Ciater, South Tangerang City. Where today you are - foster homes al - amien have started considering a business together at - in order to teach and educate. Independence. The company business startups still managed by the simple by the foster homes with management manjemen not yet well and still is a routine, especially about the importance of the management of financial management.

\section{Keyword : Entrepreneurship, Financial Management}

\section{PENDAHULUAN}

Sampai dengan saat ini di tahun 2020 perkembangan wirausaha di Indonesia masih cukup kecil dan terbatas. Dimana pada awal tahun 2020 angka wirausaha di Indonesia sebesar 3,5 persen dari total jumlah penduduk. Rasio tersebut masih lebih rendah dibandingkan dengan negara-negara lain seperti Singapura yang angka wirausahanya 7 persen , China 10 persen, Jepang 11 persen, da Malaysia 5 persen. Saat ini tingkat kewirausahawan Indonesia menempati peringkat 94 dari 137 negara. Dimana fenomena di Indonesia masih banyak lulusan SLTA atau perguruan tinggi yang berbondong bondong memilih menjadi karyawan daripada menjadi wirausahawan. Pada tahun 2030 pemerintah Indonesia menargetkan angka wirausahawan mencapai sebanyak 4 persen dari total penduduk. Berdasarkan data tersebut maka sudah semestinya diperlukan pelatihan kewirausahaan secara bertahap sejak usia dini, baik untuk masyarakat umum dan lebih khusus pada rumah yatim piatu.

Pelatihan penguatan wirausaha pada rumah yatim piatu ditujukan agar anak panti asuhan dan seluruh pengelola dapat memiliki kemampuan manajemen keuangan yang baik dan kemandiria dalam berwirausaha. Hal tersebut disiapkan sejak dini dari awal dimulainya kegiatan wirausaha agar kedepannya kemampuan ini dapat mendukung proses berwirausaha dengan sangat maksimal dan tepat perhitungan sehingga usaha yang ditekuni dapat berkembang terus menerus dari waktu ke waktu.

Berdasarkan pada hal tersebut diatas maka akan dilaksanakan Pengabdian Kepada Masyarakat ( PKM ) di Rumah yatim piatu Al-Amiin, Ciater 
Kota Tangerang Selatan. Dimana saat ini anak-anak panti asuhan Al-Amiin sudah memulai merintis usaha secara berasama-sama guna mengajarkan dan mendidik kemandirian. Usaha yang saat ini mulai dirintis bergerak dibidang makanan yakni kantin yang selanjutnya akan merintis usaha salon kecantikan khus pemasanga bulu mata. Rintisan usaha tersebut masih dikelola secara sederhana oleh anak - anak panti asuhan dengan manjemen pengelolaan yang belum baik dan masih bersifat rutinitas dan manual, terutama pada manajemen keuangannya. Dalam pelaksanaan ada tahapan metode Pengabdian yang dilakukan mulai dari pengumpulan data teknik perhitungan keuangan, analisa pelaksanan usaha dan sistem manajemen yang diterapkan. Selanjutnya kami simpulkan masalah yang muncul dan kami lakukan penyusunan materi pendukung yang berguna untuk pemecahan masalah dan sekaligus merancangkan kegiatan serta panduan manajemen keuangan yang tepat.

Pada pelaksanaan pengabdian dilakukan pelatihan dan dilanjutkan pendampingan pelaksanaannya pada hari hari selanjutnya lalu kemudian dilakukan evaluasi secara menyeluruh dan bertahap untuk memastikan tercapainya manajemen keuangan yang baik dan usaha kantin menjadi meningkat dan lebih baik dan akan bisa berkembang dengan bentuk kewirausahaan yang lainnya. Sebenarnya apa permasalahan yang ada pada Usaha Kantin di Rumah yatim piatu Ciater?

\section{METODE KEGIATAN \\ PELAKSANAAN}

Dalam kesempatan ini mekanisme kegiatan Program Kemitraan Masyarakat (PKM) terdiri atas enam tahapan, yakni tahap persiapan, investigasi, pembekalan, praimplementasi, evaluasi, serta implementasi. Pada tahapan persiapan dilakukan survey lokasi dan koordinasi dengan mitra. Pada tahapan investigasi yang dilakukan adalah menggali komponen-komponen permasalahan yang tengah dihadapi mitra, mendengarkan berbagai keluhan mitra dalam menjalankan usahanya serta keinginan dan harapan mitra terhadap wirausaha yang tengah dirintisnya. Pada tahapan investigasi ini juga dilakukan identifikasi produk yang dimiliki mitra, menggali keterampilan, manajemen usaha, kegiatan administrasi dan pembukuan yang dimiliki mitra dan telah dijalankan dalam berwirausaha serta kegiatan promosi yang telah dilakukan.

Selain itu, pada tahapan investigasi ini juga akan digali potensi dan ide kreatif dari mitra yang belum terealisasi dan termanfaatkan. Sementara itu, tahapan pembekalan dibagi menjadi beberapa bagian, yaitu pembekalan pengembangan pembuatan produk unggulan melalui inovasi kemasan parfum, pembekalan pelatihan manajemen usaha, pembekalan sistem administrasi dan pembekalan penyusunan laporan keuangan sederhana, serta pembekalan perluasan jaringan pemasaran produk.

Sementara itu, pada tahap praimplementasi dilakukan penerapan ilmu pengetahuan dan keterampilan yang telah diperoleh selama tahapan pembekalan. Pada tahapan ini juga digunakan untuk mengetahui nilai tambah dari kegiatan pengabdian PKM yang telah dilakukan. Pada tahapan ini dapat diketahui apakah masih terdapat hal-hal yang perlu untuk diperbaiki dan bagaimana cara penerapannya.

Pada tahap evaluasi dilakukan evaluasi hasil pra implementasi serta kendala-kendala yang dihadapi untuk dijadikan dasar dalam melakukan perbaikan. Terakhir adalah tahapan implementasi yang merupakan penerapan secara berkelanjutan ilmu pengetahuan dan keterampilan yang telah diperoleh selama kegiatan 
pengabdian PKM berlangsung.

Pada kesempatan ini

implementasi ilmu pengetahuan dan

keterampilan yang diterapkan secara berkelanjutan diharapkan dapat mengembangkan kelompok masyarakat Panti Asuhan Al-Amien menjadi mandiri secara ekonomi dan sosial, membantu menciptakan ketentraman, kenyamanan dalam kehidupan bermasyarakat, dan meningkatkan keterampilan dalam berwirausaha. Pendekatan yang dilakukan untuk menyelesaikan persoalan mitra meliputi pendekatan partisipatif, metode pendekatan ceramah, serta diskusi baik kelompok dan individu.

a. Metode Pendekatan Partisipatif. Metode ini digunakan agar mitra dapat berpartisipasi aktifterhadap seluruh rangkaian kegiatan yang akan dilaksanakan. Pendekatan ini diawali dengan kegiatan bertemu secara langsung dengan pelaku usaha yang telah sukses. Hal ini dilakukan untuk memberikan motivasi, inspirasi, membangun niat, menumbuhkan semangat mitra untuk terus melakukan inovasi pengembangan usaha serta mengikuti dengan seksama proses kegiatan Program Kemitraan Kemasyarakatan (PKM).

b. Metode Pendekatan Ceramah. Cara yang paling efektif untuk memperkenalkan informasi atau konsep-konsep yang baru pada sekelompok orang yang belajar. Dalam metode pendekatan ini dilakukan presentasi mengenai konsep dan informasi dalam cara yang sistematis dalam waktu yang terbatas, menggunakan alat bantu, berdiskusi dengan mitra.

c. Metode Pendekatan diskusi. Pada metode ini dilakukan sharing pengalaman dalam proses pembelajaran dengan cara: (a) Memberikan kesempatan kepada mitra untuk saling berbagi pengalaman, gagasan, ide, dan mengklarifikasi sudut pandang mitra yang berbeda (b) Membantu mitra mengenali apa yang mereka telah lakukan dan hal-hal yang mitra tidak ketahui (c) Membantu mitra menjawab pertanyaanpertanyaan yang selama ini mereka temui dalam pengalaman, meningkatkan keterlibatan mitra dalam menajalankan usahanya.

d. Pendekatan Kelompok dan Individual. Dalam metode pendekatan kelompok dan individual ini digunakan pembelajaran dengan melakukan pembelajaran melalui pengamatan. Hal-hal yang dilakukan adalah dengan pelatihan pengelolaan sistem administrasi, pelatihan penyusunan laporan keuangan sederhana, pelatihan pembuatan web/media sosial lainnya untuk kegiatan promosi. Di setiap akhir pelaksanaan kegiatan mitra diberikan angket untuk mengetahui seberapa besar tingkat pemahaman terhadap materi dan program yang telah diberikan.

\section{HASIL DAN PEMBAHASAN}

Pembinaan tentang manajemen usaha dalam kewirausahaan sosial khususnya mengenai penyuluhan dan pemberian materi dan demo praktek salon kecantikan khusus Pemasangan Bulu Mata dengan konsentrasi pada pengelolaan Keuangan sejak dini juga sangat diperlukan guna mendukung kemandirian pada anak serta menumbuhkan jiwa kewirausahaan sosial sejak dini. Mengingat dari segi usia anak-anak di Rumah yatim piatu Al - Amien Ciater Kota Tangerang 
Selatan, sebagian besar berada pada usia pra remaja dan remaja. Usia tersebut merupakan usia produktif dan diharapkan saat ini mampu mengisi waktu yang dimiliki dengan berbagai aktivitas yang bermanfaat guna menambah pengetahuan dan wawasan keterampilan yang memadai. Dengan adanya pengetahuan dan wawasan keterampilan yang memadai kelak menjadi bekal untuk dapat bermetamorfosis menjadi pribadi mandiri yang tidak hanya dapat berguna bagi dirinya, namun juga mampu memberikan kemaslahatan bagi masyarakat dan alam semesta selepas dari kehidupan di Panti Asuhan.

Sedagkan pelaksanaan pengabdian kepada masyarakat ini akan dimulai dengan penyuluhan dan pemberian materi dan demo praktek salon kecantikan khusus Pemasangan Bulu Mata dengan konsentrasi pada pengelolaan keuangan. Para peserta sudah tidak asing lagi karena mereka sudah terbiasa dan merupakan pelaku usaha, tetapi tidak menutup kemungkinan peserta kurang memahami apa yang dimaksud dengan usaha kecil. Usaha kecil merupakan usaha yang mempunyai jumlah tenaga kerja kurang dari 50 orang, atau berdasarkan Undang-Undang Nomor 9 Tahun 1999 kategori usaha kecil adalah yang memiliki kekayaan bersih paling banyak Rp. 200.000.000,00 (tidak termasuk tanah dan bangunan); penjualan paling banyak $\mathrm{Rp}$. 1.000.000.000,00; milik Warga Negara Indonesia, bukan afiliasi badan usaha lain (berdiri sendiri), dan berbentuk usaha perorangan, badan usaha, atau koperasi. Pada pelaksanaanya di Rumah yatim piatu ini bergerak dibidang makanan yakni kantin. Sebuah usaha kecil yang bertujuan untuk menggerakkan perekonomian dan mengajarkan pentingnya usaha guna memupuk kemandirian anak anak panti asuhan.

Adapun permasalahan yang tengah dihadapi Rumah yatim piatu Al - Amien Ciater Kota Tangerang Selatan merupakan permasalahan yang sangat mendesak untuk dicarikan solusinya. Permintaan pelatihan dan pendampingan dari mitra dapat diwujudkan melalui Program Kemitraan Masyarakat (PKM) ini yang bertujuan:

1. Mengelola keuangan dari hasil usaha agar bisa mendapatkan keuntungan yang maksimal.

2. Mengembangkan kelompok masyarakat yang bernaung di Panti Asuhan Al-Amien Ciater menjadi mandiri secara ekonomi dan sosial;

3. Membantu menciptakan ketenteraman, kenyamanan dalam kehidupan bermasyarakat;

4. Meningkatkan keterampilan dalam berwirausaha;

Setelah pengabdian ini dilaksanakan maka tahapan berikutnya pengabdi akan melakukan pendataan dari hasil pelatihan terutaman mengenai Tanya jawab peruhal bagaimana cara mengajukan pinjaman ke Kredit Usaha Rakyat KUR di Bank BRI cabang terdekat, yang selanjutnya akan kita berikan rekomendasi atau langkah untuk merealisasi pengajuan KUR tersebut dan menghubungkannya dengan Petugas atau pimpinan Bank terdekat dengan merekomendasikan atas usaha kantin yang telah dilakukan oleh Rumah yatim piatu. Selain itu dilakukan tahapan penyuluhan dan pendampingan pelaksanaan manajemen sumber daya manusia secara berkesinambungan hingga peserta cukup mandiri dalam pelaksanaanya.

Setelah itu pengabdi membuat laporan hasil dan melakukan submit jurnal luaran wajib berupa jurnal 
nasional yang dikelola Lembaga Penerbit Jurnal Universitas Pamulang tahun 2021. Pengabdian ini merupakan pengabdi dengan bidang fokus konsentrasi manajemen keuangan, sehingga untuk melaksanakannya semua pengabdi menguasai bidangnya. Target akhir dari harapan Pengabdi bahwa program ini dapat membantu perekonomian Rumah yatim piatu Ciater dalam memenuhi kebutuhan perekonomian dan memberikan pembelajaran kepada anak - anak panti agar memiliki bekal usaha yang baik dalam menyongsong masa depan yang gemilang sebagai pelopor pencipta usaha dimasa yang akan datang. Namun jika program ini hanya dilaksanakan oleh segelintir orang atau kelompok saya yakin tidak akan terlaksana. Tetapi dengan adanya pengabdian dan pembimbingan secara berklenajutan dengan para ahli yang handal pasti program ini akan terlaksana dengan mengsinergikan dengan berbagai pihak.

Berikutnya akan kami sampaikan beberapa dokumen pelaksanaan kegiatan pengabdian kepada masyarakat yang dilaksanakan oleh kelompok Dosen Universitas Pamulang yang bisa memberikan gambaran pelaksanaan kegiatan, kegiatan dilaksanakan pada tanggal 3 sampai dengan 5 April 2021. Dilaksanakan oleh 5 Dosen dan 3 mahasiswa serta 25 santri yang didampingi oleh ketua Yayasan, Kepalas Sekolah serta 1 staf keuangan, juga hadir pula lingkungan masyarakat sekitar. Adapun dokumen tersebut antara lain dapat diliahat di bawah ini :
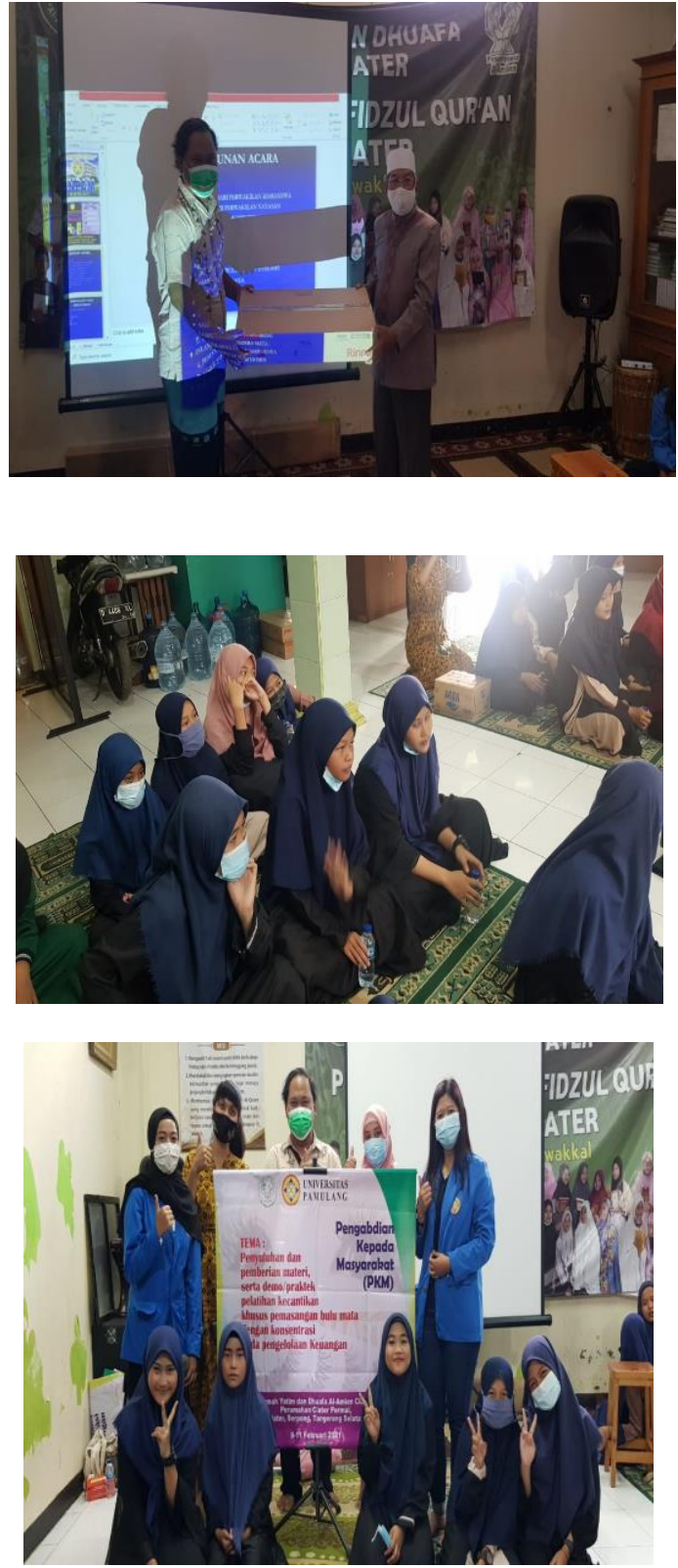

\section{DAFTAR PUSTAKA}

Ridwan, 2020 Industry.co.id : Kemenkop dan UKM Dorong Generasi Muda Berkarya Kreatif dan Inovatif (https://www.industry.co.id/read/61 095/kemenkop-dan-ukm-dorong generasi-mudaberkarya-kreatifdan-inovatif )

Umum, 2020 kabarbisnis.com : https://www.kabarbisnis.com/read/ 2897671/jumlah-wirausahaindonesia-ditargetkan-4- 
persenpada-2030 )

Brigham, Houston, 2019, Dasar - Dasar

Manajemen Keuangan : Salemba Empat, Jakarta

Astuti, Dewi. 2004. Manajemen Keuangan Perusahaan. Jakarta: Ghalia Indonesia.

Brigham, Eugene $F$ dan Joel $F$. Houston. 2006. Dasar dasar Manajemen Keuangan. Edisi Sepuluh. Terjemahan oleh Ali Akbar Yulianto. Buku Dua . Jakarta: Salemba Empat, Jakarta

Darmadji, Tjiptono, 2008, Pasar Modal di Indonesia, Penerbit : Salemba Empat, Jakarta

Darsono, dan Ashari, 2005, Pedoman Praktis Memahami Laporan Keuangan, edisi pertama, Penerbit : Andi, Yogyakarta.

Pasaribu, V. L. D., Agrasadya, A., Shabrina, N., \& Krisnaldy, K. (2020). Menjadi Enterpreneur Muda Yang Memiliki Jiwa Leadership Untuk Menghadapi Masa Depan. Abdi Laksana: Jurnal Pengabdian Kepada Masyarakat, 1(1).

Pasaribu, V. L. D., Susanti, F., \& Hartuti, E. T. K. (2019). Memotivasi Siswa dan Siswi SMK Letris Indonesia di Dalam Menentukan Pilihan Untuk Melanjutkan Pendidikan Atau Bekerja Setelah Lulus Sekolah. Jurnal Pengabdian Dharma Laksana, 1(2), 161-172.

Pasaribu, V. L. D., Sulaiman, S., Sutiman, S., Thaharudin, T., \& Purnomo, B. Y. (2020). Pengenalan Letak Posyandu Terdekat Dikelurahan Pisangan Dengan Manajemen Pemasaran Revolusi 4.0 Untuk
Meningkatkan Pengetahuan Masyarakat Letak Dan Fungsi Posyandu Terdekat Pada Kelurahan Pisangan. Dedikasi Pkm, 1(1), 105-110.

Pasaribu, V. L. D., Oktrima, B., Prabowo, B., Arianto, N., \& Haryoko, U. B. (2020). Progam Pendampingan Dan Penyelenggaraan Pendidikan Anak Pada Usia Dini Terhadap Prestasi Belajar Dilingkungan Rt $020 \mathrm{Rw}$ 009. Kel Giri Peni. Kec Wates. Yogyakarta. Jurnal Lokabmas Kreatif, 1(1), 71-75.

Pasaribu, V. L. D., Jannah, M., Fazar, M., Putra, S. P., Monalisa, M., \& Sofa, M. (2021). MENINGKATKAN PRODUKTIVITAS USAHA DIMASA PANDEMI PADA IBU PKK RT 004/003 KELURAHAN SAWAH BARU CIPUTAT, TANGERANG SELATAN. Abdi

Laksana: Jurnal Pengabdian Kepada Masyarakat, 2(2), 295301.

Pasaribu, V. L. D., Yuniati, H. L., Pranata, R., Sembayu, R., Purba, S. M., \& Nurbayani, T. T. A. (2021). MANAJEMEN KEUANGAN UNTUK MENGHADAPI DAN BERTAHAN DI ERA COVID 19. Jurnal Abdimas Tri Dharma Manajemen, 2(2), 12-18.

Pasaribu, V. L. D., Dwiyatni, A., Sabina, C., Ridwan, M., Gunawan, D. D., \& Noviani, B. C. (2021). EVALUASI PENERAPAN 3M DIMASA PANDEMIC COVID 19. Jurnal Abdimas Tri Dharma Manajemen, 2(2), 54-60.

Pasaribu, V. L. D., Syafei, A. N., Farhan, A., Aufaizah, A., Irani, C., \& Firtiayani, S. R. (2021). PENGARUH DISPLIN 
PROTOKOL KESEHATAN

TERHADAP PENCEGAHAN

PENULARAN VIRUS COVID-

19. Jurnal Abdimas Tri Dharma

Manajemen, 2(2), 91-98.

Pasaribu, V. L. D., Septiani, F., Rahayu, S., Lismiatun, L., Arief, M., Juanda, A., ... \& Rahim, R. (2021). Forecast Analysis of Gross Regional Domestic Product based on the Linear Regression Algorithm Technique.

Priadi, A., Pasaribu, V. L. D., Virby, S., Sairin, S., \& Wardani, W. G. (2020). Penguatan Ekonomi Kreatif Berbasis Sumber Daya Desa Dikelurahan Rempoa. Abdi Laksana: Jurnal Pengabdian Kepada Masyarakat, 1(3), 356-35

Supatmin, 2020, Manajemen Keuangan Konsep Dasar dan Penerapannya, Edisi Pertama, Penerbit: AA Rizky, Tangerang.

https://kumparan.com/edy-saputra1607916770571917671/pantiasuhan-pondok-yatim-and dhuafalumHCq30H4V\#: :text=Po ndok $\% 20$ Yatim $\% 20 \% 26 \% 20$ Dhuaf a\%20adalah\%20Panti,dan\%20dhu afa\%20yang\%20kurang\%20berunt ung.

https://text-

id.123dok.com/document/wyevjpo ez-pengertian-anak-yatim-piatudan-dhuafa. 